\section{Revolution og reaktioner}

Edmund Burke: Tanker om den franske revolution. Tidehvervs Forlag, Tønder 1987, 252 s., kr. 259. Oversat af Christian Truelsen.

Den klassiske konservatismes hoffilosof foreligger med denne udgivelse for første gang på dansk. I form af et 250 sider langt brev til en ven i $\mathrm{Pa}$ ris, fremlagde Burke i 1790 sine tanker om den franske revolution.

Bogen blev øjeblikkelig en bibel i anti-revolutionære kredse, og Burke kunne i triumf aflægge en visit hos emigranterne i Koblenz. At Burkes bog fremdeles virker i vor tid kan undre. Bogen er en minutiøs beskrivelse og analyse af de hektiske begivenheder omkring revolutionens første fase, men Burkes valg af den tidstypiske brevform står i dag i vejen for hans budskab, der drukner eller udvandes i detailstudier, hvis sigte og omfang mildt sagt virker antikveret. Oversætteren Chr. Truelsens indledning og noter hjælper ikke meget til den afstøvning, Burkes bog i udpræget grad behøver i forhold til en nutidig læserkreds, og Burkes overordentlig pedantiske gennemgang bør vel i dag kunne påkalde sig faghistorikernes kritiske blik.

Det er snarere de spredte, usystematiske socialfilosofiske overvejelser, der godtg $ø r$ Burkes idehistoriske relevans ogrimeligheden $i$ at genududgive den netop nu. Netop fordi de her er formuleret op imod revolutionens princippe $\mathrm{r}$ og idealer, er Tanker om den franske revolution stadig et vigtigt skrift til forståelsen af ikke bare verserende neo-konservatisme, men også af romantikkens socialfilosofi.

I sin reneste form lyder Burkes "konservatisme": "Vi ønskede på revolutionens tid (i.e. den engelske anno 1688) og ønsker nu at udlede alt, hvad vi ejer, af arven fra vore forfadre. Vi har gjort os umage for ikke på denne arvestamme at indpode nogen kvist, som var fremmed for den oprindelige plantes natur. Alle de reformer, vi hidtil har indført, er udsprunget af princippet om respekt for det, der stammer fra gammel tid, og jeg håber, ja jeg er overbevist om, at alle de ændringer, som herefter måtte blive foretaget, vil blive formet omhyggeligt på samme måde, byggende på præcedens, autoritet og exempel" (p. 33-34). Englænderne har i denne forstand arvet deres frihedsrettigheder, de er således uafhændelige, erhvervede rettigheder, men netop ikke principielle, universalistiske menneskerettigheder.

Burke angriber på det kraftigste de amerikanskemenneskerettigheder for deres rationalisme og nivellerende konsekvenser. De eksploderer den træge praksis og de lader hånt om lokale og partikulære forhold.

Når årsagen til forgiftningen af brøndene skal søges er Burke ikke et sekund i tvivl. Med væmmelse denuncierer han: "Filosofi, oplysning, fordomsfrihed (sic!), menneskerettigheder." Burkes bekymring angår, hvad han kalder den nøgne fornuft. Det er den blinde rationalisering og oplysning, der fejer alle de naturgroede privilegier og standsforskelle væk. Burke modstiller den klassiske "Entzauberungstese" med fordommens nærende virkning: "Vi englændere er i alminde- 
lighed mennesker med primitive følelser, at vi i stedet for at bortkaste alle vore gamle fordomme i høj grad varner om dem, fordi de er fordomme...Fordommen gør retskaffenheden til vane...den $g \varnothing \mathrm{r}$ pligten til en del af hans natur" (p. 87-88).

I sådanne formuleringer udarter Burkes "tanker" til en barbarisk kynisme, som grunder sig på en underlig rådvildhed og afmægtighed over for det faktum, at revolutionen i det hele taget var mulig. For Burke er revolutionen "det mest forbavsende, der hidtil er hændt i verden" (p. 14), men hans tanker om den er totalt paralyserede. De formår ikke rigtig at stille noget op med skandalen.

Burkes "Tanker" fortjener således læsere, der ikke kun søger at stilisere ham til et profetisk orakel.

Som politisk tænker er det ikke, man i dag bør læser Burke. Snarere bør man pode ham på eksempelvis den tyske romantiske organologi og socialfilosofi, eller analysere hans få, spredte bemærkninger om massen, eller simpelthen læse ham som et lærestykke i teorisk paralyse.

\section{Henrik Ørnstrup}

\section{Filosofi i samtale}

Florian Rötzer: Samtaler med franske filosoffer. Akademisk Forlag. København 1988, 151 s. Oversat af Finn Frandsen og Jens Erik Kristensen.

Bogen Samtaler med franske filosoffer, som nu er udgivet på Akademisk Forlag, er et interessant fænomen på flere måder. Således drejer det sig om en oversættelse til dansk af en tysk bog indeholdende samtaler med en række franske filosoffer. Dette tresprogsfænomen bevidner en gevaldig internationalisering $\mathrm{i}$ og for den filosofiske tænkning i dag. Tendensen har været tydelig - og tydeligt tiltagende - de sidste tyve år: anglo-amerikanske filosoffer (Rorty og Cavell f.eks.) med analytisk baggrund begynder at interessere sig for en ellers hos dem anathematiskkontinental tradition, lige som tysksprogede filosoffer (Habermas og Wellmer f.eks.) har fået øjnene op for både den analytiske tradition, pragmatismen og den dekonstruktive konjunktur. I Frankrig er der også - omend mærkbart i mindre grad end i det tysksprogede område og i USA - tendenser til ikke blot (som det her altid har været tilfældet) at orientere sig $\mathrm{i}$ "fortidens udenlandske" (fortrinsvist tysksprogede) filosofi, men tillige at have antennerne ude, hvad angår samtidens tyske og amerikanske filosofi (dette ses bl.a. hos Lyotard og Derrida). Kun England synes endnu filosofisk at indtage en traditionel insulær position, hvad grundene til dette end måtte være. Med andre ord er filosofien og den filosofiske diskussion ved at blive 